\title{
Efektivitas Program Klaster Bank Indonesia Terhadap Peningkatan Pendapatan Petani Cabai Kelompok Juli Tani, Desa Sidodadi, Kecamatan Beringin, Kabupaten Deli Serdang Effectiveness of Indonesia Bank Cluster Program Towards the Income of Chili Farmers of Juli Tani, Sidodadi Village, Beringin District, Deli Serdang Regency
}

\author{
Rinaldi Simamora, Ahmad Rafiqi Tantawi, \& Mitra Musika Lubis \\ Unversitas Medan Area, Indonesia \\ Diterima: April 2021 Direview: April 2021 Disetujui: April 2021 \\ *Corresponding author: E-mail: rinaldisimamora05@gmail.com
}

\begin{abstract}
Abstrak
Penelitian ini bertujuan untuk mengetahui efektivitas Program Klaster Bank Indonesia terhadap tingkat pendapatan petani cabai pada Kelompok Juli Tani di Desa Sidodadi, Kecamatan Beringin, Kabupaten Deli Serdang. Data yang digunakan merupakan data primer yang diperoleh langsung dari sampel petanicabaimerahyangada di KelompokJuli Tani dengan menggunakan kuesioner. Penentuan sampeldalam penelitian ini menggunakan metode slovin dengan jumlah sampel sebanyak 52 responden. Analisis data yang digunakan dalam penelitian ini yaitu dengan (1) Analisis Efektivitas Program Klaster (2) Analisis pendapatan usaha tani, untuk mengetahui usahatani menguntungkan atau tidak secara ekonomi peneliti mengggunakan Revenue Cost Ratio (R/C Ratio) selanjutnya (3) digunakan statistik non parametrik dengan uji korelasi Rank Spearman. Berdasarkan hasil penelitian diketahui bahwa program klaster yang diberikan oleh Bank Indonesia sangat efektif terhadap peningkatan pendapatan petani cabai merah pada Kelompok Juli Tani di Desa Sidodadi, Kecamatan Beringin, Kabupaten Deli Serdang dengan rata-rata pendapatan petani sebesar Rp117.404.895 per musim tanamnya.
\end{abstract}

Kata Kunci: efektivitas; pendapatan; usahatani cabai merah

\begin{abstract}
Juli Tani Group is a farmer group that received the cluster program from Bank Indonesia of Sumatera Utara for the red chili commodity. This study aims to determine the effectiveness of Bank Indonesia Cluster Program on the income level of chili farmers in the Juli Tani Group in Sidodadi Village, Beringin District, Deli Serdang Regency. The data used are primary data obtained directly from the sample of red chili farmers in Juli Tani Group using a questionnaire. Determination of the sample in this study using the Slovin method with a total sample of 52 respondents. Analysis of the data used in this research were (1) Analysis of the Effectiveness of the Cluster Program (2) Analysis of farm business income, to determine whether farming is profitable or not economically, the researcher uses Revenue Cost Ratio ( $R$ / C Ratio) then (3) uses non-statistical parametric with the Spearman Rank correlation test. Based on the research results, it was known that the Bank Indonesia cluster program is very effective in increasing the income of chili farmers in the Juli Tani Group in Sidodadi Village, Beringin District, Deli Serdang Regency with an average farmer income of $\mathrm{Rp} 117,404,895$ per growing season.
\end{abstract}

Keywords: effectiveness; income; red chili farming

How to Cite: Simamora, R. Tantawi, A.R \& Lubis, M.M (2021). Analisis Saluran Pemasaran Melon Kuning di Kecamatan Pantai Labu Kabupaten Deli Serdang. Jurnal Agriuma. 3 (1): 31-39. 
Komoditas hortikultura merupakan komoditas potensial yang mempunyai nilai ekonomi tinggi dan memiliki potensi untuk terus dikembangkan. Sisi permintaan pasar, jumlah penduduk yang besar, kenaikan pendapatan, dan berkembangnya pusat kota-industri-wisata, serta liberalisasi perdagangan merupakan faktor utama yang mempengaruhi permintaan (Rahardi, 2007). Berdasarkan catatan Ditjen Hortikultura, Departemen Pertanian (2004), cabai merah mengandung banyak zat gizi yang sangat diperlukan untuk kesehatan tubuh manusia. Cabai merah mengandung protein, lemak, karbohidrat, kalsium, fosfor, besi, vitamin-vitamin, dan senyawa-senyawa alkaloid, seperti capsaicin, flavenoid, serta minyak esensial. Cabai merah banyak digunakan sebagai bahan baku industri pangan. Meskipun cabai merah bukan bahan pangan utama masyarakat Indonesia, namun komoditas ini tidak dapat ditinggalkan. Selain itu, cabai memiliki nilai ekonomi yang tinggi dan mempunyai daya adaptif yang tinggi karena dapat tumbuh di dataran tinggi maupun dataran rendah.

Dalam melakukan usahatani cabai banyak sekali permasalahan yang dihadapi petani, sehingga harus lebih teliti dalam mempertimbangkan segala sesuatunya. Salah satunya yaitu sering terjadinya fluktuasi harga. Kenaikan harga cabai sangat tergantung pada musim panen dan musim tanam serta pengaruh iklim cuaca. Disamping itu, kenaikan harga juga berkaitan dengan kegiatan pemasaran. Beberapafaktoryangmempengaruhi diantaranyafaktor angkutan, rendahnya daya tahan cabai dan daya beli masyarakat.

Sesuai dengan perannya yaitu menjaga stabilitas moneter dan juga stabilititas keuangan, Bank Indonesia mempunyai peran yang sangat penting dan strategis dalam membantu perkembangan dunia usahatani dan sektor usaha lainnya. Namun peran tersebut dapat terwujud apabila petani dibekali dengan konsep, kemampuan, pengetahuan, dan strategi yang memadai untuk membentuk petani yang handal dalam mengelola usahatani baik dalam manajemen maupun teknis (Santika, 1999)

Pemberdayaan petani perlu diselenggarakan secara menyeluruh, optimal, dan berkesinambungan melalui pengembangan iklim yang kondusif, dukungan, perlindungan sehingga mampu meningkatkan potensi petani dalam mengelola usahataninya serta mewujudkan pertumbuhan ekonomi, pemerataan dan peningkatan pendapatan petani serta pengentasan rantai kemiskinan (Zikria et al., 2019).

Saat ini Bank Indonesia melaksanakan beberapa program yang terdiri dari Program UMKM dan Sektor Riil dari Wirausaha Bank Indonesia (WUBI), program Klaster dan program lainnya. Program ini diharapkan mampu meningkatkan kapasitas ekonomi nasional serta membantu tugas Bank Indonesia dalam menjaga kestabilan nilai tukar rupiah yang tercermin dari banyaknya barang dan jasa yang dihasilkan masyarakat (DKBU Bank Indonesia, 2008).

Pemberian program pengembangan klaster oleh Bank Indonesia merupakan bagian dari upaya percepatan pertumbuhan sektor rill yang dilakukan melalui pengembangan usahatani dengan pendekatan program klaster. Dasar pertimbangan memilih pendekatan klaster oleh Bank Indonesia tersebut karena nilai strategis pendekatan ini yang terintegrasi, meningkatkan daya tawar, efisiensi biaya dan berdampak bagi pengembangan ekonomi wilayah. Pendekatan klaster juga mampu mendorong inovasi melalui pertukaran pengalaman antar pelaku dalam hubungan hulu kehilir serta mendorong peningkatan keterkaitan sosial dan peningkatan keahlian masaing-masing anggota klaster. Maka konsep pengembangan program klaster Bank Indonesia diarahkan untuk membangun faktorfaktor model dan memperkuat modal sosial para pelaku klaster (DKBU Bank Indonesia, 2008).

Kantor Perwakilan Bank Indonesia Sumatera Utara melakukan pembinaan program klaster pada Kelompok Juli Tani. Kelompok Juli Tani sendiri berlokasi di Desa Sidodadi, Kecamatan Beringin, Kabupaten Deli Serdang. Adapun tujuan Kantor Perwakilan Bank IndonesiaSumateraUtara melakukan program klaster di Kelompok Juli Tani adalah untuk meningkatkan dan mengembangkan kemampuan petani sebagai subjek pembangunan pertanian serta untuk mendukung pengendalian harga dan 
Rinaldi Simamora, Ahmad Rafiqi Tantawi, \& Mitra Musika Lubis, Efektivitas Program Klaster Bank Indonesia Terhadap Peningkatan Pendapatan Petani Cabai Kelompok Juli Tani

pengembangan ekonomi daerah melalui pendekatan kelompok agar lebih berperan dalam pembangunan.

Maka dari itu penulis tertarik untuk melakukan penelitian dengan judul "Efektivitas Program Klaster Bank Indonesia Sumatera Utara Terhadap Tingkat Pendapatan Petani Cabai (Studi Kasus : Kelompok Juli Tani, Desa Sidodadi, Kecaamatan Beringin, Kabupaten Deli Serdang)”. Adapun tujuan penelitian ini adalah untuk mengetahui efektifitas Program Klaster Bank Indonesia terhadap tingkat pendapatan petani cabai pada Kelompok Juli Tani di Desa Sidodadi, Kecamatan Beringin, Kabupaten Deli Serdang.

\section{METODE PENELITIAN}

Penelitian ini dilaksanakan di Kelompok Juli Tani yang terletak di Desa Sidodadi, Kecamatan Beringin, Kabupaten Deli Serdang, Provinsi Sumatera Utara pada bulan November sampai Desember 2019 yang ditentukan dengan cara sengaja (purposive) dengan pertimbangan hanya Kelompok Juli Tani yang mendapatkan program klaster cabai merah di lingkungan Kantor Perwakilan Bank Indonesia Sumatera Utara.

Jumlah populasi dalam penelitian ini adalah seluruh petani cabai binaan Bank Indonesia Sumatera Utara dalam program klaster pada Kelompok Juli Tani, Desa Sidodadi sebanyak 105 petani dengan menghitung ukuran sampel yang dilakukan dengan menggunakan teknik Slovin dengan perhitungan :

$$
n=\frac{N}{1+N(e)^{2}}
$$

Keterangan:

$\mathrm{n}=$ Ukuran sampel/jumlah responden

$\mathrm{N}=$ Ukuran populasi

$\mathrm{E}=$ Presentase kelonggaran ketelitian kesalahan pengambilan sampel yang masih bisa

ditolerir; $\mathrm{e}=0,1$

Maka untuk mengetahui sampel penelitian, dengan perhitungan sebagai berikut:

$$
n=\frac{105}{1+105(0,1)^{2}}
$$

$$
n=\frac{105}{2,05}=51,21 \text {; dibulatkan oleh peneliti menjadi } 52 \text { responden }
$$

Berdasarkan perhitungan diatas sampel yang mejadi responden dalam penelitian ini dibulatkan sebanyak52 responden daripopulasi, hal ini dilakukan untukmempermudah dalam pengolahan data dan untuk hasil pengujian yang lebih baik. Sampel yang diambil berdasarkan teknik probability sampilng; simple random sampling, dimana peneliti memberikan peluang yang sama bagi setiap anggota pupulasi (petani) untuk dipilih menjadi sampel yang dilakukan secara acak tanpa memperhatikan strata yang ada dalam populasi itu sendiri.

Pengumpulan data dalam penelitian ini menggunakan beberapa metode yaitu wawancara dan kuesioner. Dalam penelitian ini kuesioner yang digunakan adalah kuesioner tertutup yang jawabannya sudah tersedia dan responden memberikan jawaban alternatif pada jawaban yang telah tersedia. Melalui penyebaran angket yang berisikan beberapa pertanyaan yang akan diajukan kepada responden, maka ditentukan skor pada setiap pertanyaan. Teknik pengukuran skor yang dilakukan dalam penelitian ini memakai Skala Likert untuk menilai jawaban kuesioner (Sugiyono, 2014). 


\section{Metode Analisis Data}

Metode analisis data yang digunakan dalam penelitian ini adalah analisis statistik deskriptif.

\section{Analisis Efektivitas Program Klaster}

Efektivitas program klaster dalam penelitian ini diukur dengan menggunakan produktivitas dan kepuasan peserta adalah rasio dari total output dengan input yang dipergunakan dalam produksi. Selanjutnya produktivitas dapat dihitung dengan menggunakan rumus produktivitas. Selanjutnya produktivitas dapat dihitung dengan menggunakan rumus produktivitas.

$$
\text { Produktivitas= Jumlah Produksi/Luas Lahan }
$$

Kepuasan peserta dapat dilihat dari tingkat capaian responden (TCR) yaitu dengan menghitung nilai Tingkat Capaian Responden (TCR) masing-masing kategori dari data deskriptif variabel. Selanjutnya dapat menggunakan Rumus uji TCR :

$$
T C R=\frac{R s}{n} \times 100 \%
$$

Dimana :

TCR : Tingkat Capaian Responden

Rs : Rata-rata skor jawaban sampel

n : Nilai skorjawaban

\section{Analisis Pendapatan Usaha Tani}

Pendapatan usahatani cabai merah diperoleh dengan perhitungan menggunakan rumus

$$
\pi=Y \cdot P_{y}-\sum_{X i} \cdot P_{i}
$$

Keterangan :

$$
\begin{array}{ll}
\pi & \text { : Pendapatan usaha tani cabai } \\
\mathrm{Y} & \text { : Produksi cabai }(\mathrm{Kg}) \\
\mathrm{Py} & \text { : Harga cabai }(\mathrm{Rp}) \\
\mathrm{Xi} & \text { : Penggunaan faktor ke-i } \\
\mathrm{Pi} & \text { : Harga faktor ke-i per unit }
\end{array}
$$

Untuk mengetahui usaha tani menguntungkan atau tidak secara ekonomi dapat dianalisis menggunakan nisbah atau perbandingan antara penerimaan dengan biaya (Revenue Cost Ratio R/C). Secara matematis $\mathrm{R} / \mathrm{C}$ dapat dituliskan :

$$
\mathrm{R} / \mathrm{C}=\mathrm{PT} / \mathrm{BT}
$$

Dimana :

R/C :Nisbah penerimaan danbiaya

PT : Penerimaan total(Rp)

BT : Biaya total (Rp)

Kriteria pengambilan keputusan adalah :

a. Jika $\mathrm{R} / \mathrm{C}>1$, maka usahatani mengalami keuntungan, karena penerimaan lebih besar dari biaya.

b. Jika $\mathrm{R} / \mathrm{C}<1$, maka usahatani mengalami kerugian, karena penerimaan lebih kecil dari biaya. 


\section{Uji Korelasi Rank Spearman}

Uji korelasi rank spearman dilakukan dengan menggunakan SPSS. Menurut Siegel (1997) rumus koefisien korelasi rank spearman (rs) adalah:

Keterangan :

$$
r s=\frac{\begin{array}{c}
n \\
1-6 \sum d i^{2}
\end{array}}{n^{3}-n}
$$

rs : Koefisien korelasi Spearman

n : Jumlah responden petani

di : Perbedaan setiap pasangan rank

Kriteria pengambilan keputusan :

a. Jika nilai signifikansi $\leq 0,05$, maka hipotesis $\mathrm{H}_{1}$ diterima, $\mathrm{H}_{0}$ ditolak pada $(\alpha)=0,05$ yang berarti ada hubungan yang signifikan antara variabel-variabel yang diuji.

b. Jika nilai signifikansi $>0,05$, maka hipotesis $\mathrm{H}_{1}$ ditolak, $\mathrm{H}_{0}$ diterima pada $(\alpha)=0,05$ yang berarti tidak ada hubungan yang signifikan antara variable-variabel yang diuji.

\section{HASIL DAN PEMBAHASAN}

\section{Analisis Efektivitas Program Klaster}

Efektivitas program klaster dalam penelitian ini diukur dengan menggunakan produktivitas dan kepuasan peserta adalah rasio dari total output dengan input yang dipergunakan dalam produksi. Produktivitas usaha tani yang dimaksud dalam penelitian adalah produktivitas usaha tani cabai pada Kelompok Juli Tani (yang mengikuti program klaster Bank Indonesia Sumatera Utara) dan usaha tani cabai pada Kelompok Sabar Tani yang terletak pada Desa Karang Anyar, Kecamatan Beringin (tidak mengikuti program klaster) yang diperoleh dalam satu kali musim panen. Adapun rata - rata produktivitas usaha tani cabai merah pada Kelompok Juli Tani, yaitu:

$$
\begin{aligned}
& \text { Produktivitas Juli Tani }=\frac{4.690 \mathrm{Kg}}{0,28 \mathrm{Ha}} \\
& \text { Produktivitas Juli Tani }=16.750 \mathrm{Kg} / \mathrm{Ha}
\end{aligned}
$$

Sedangkan rata-rata produktivitas usaha tani cabai merah pada kelompok sabar tani, yaitu :

$$
\begin{aligned}
& \text { Produktivitas Sabar Tani }=\frac{3.936 \mathrm{Kg}}{0,26 \mathrm{Ha}} \\
& \text { Produktivitas Sabar Tani }=15.138 \mathrm{Kg} / \mathrm{Ha}
\end{aligned}
$$

Produktivitas usahatani cabai dari kedua kelompok tani ini lebih besar jika dibandingkan dengan produktivitas usaha tani cabai pada Provinsi Sumatera Utara yang hanya memiliki produktivitas sebesar $9.580 \mathrm{Kg} / \mathrm{Ha}$ (Kementerian Republik Indonesia, 2019).

Selanjutnya melihat kepuasan peserta untuk mengetahui hasil program klaster pada Kelompok Juli Tani yang terdiri dari dua variabel, yaitu variabel input (kinerja program klaster) dan variable output (produksi usahatani). Kepuasan peserta dapat dilihat dari Tingkat Capaian Responden (TCR) yaitu 
dengan menghitung nilai Tingkat Capaian Responden (TCR) masing- masing kategori dari data deskriptif variabel.

Tabel 1. Distribusi Frekuensi Jawaban Responden dari Indikator Variabel Input Efektivitas Program Klaster Pada Petani Cabai di KelompokJuli Tani

\begin{tabular}{cccccccc}
\hline Pernyatan & SP & P & Jumlah & $\begin{array}{c}\text { Total } \\
\text { skor }\end{array}$ & $\begin{array}{c}\text { Rata- } \\
\text { rata }\end{array}$ & $\begin{array}{c}\text { TCR } \\
\text { (\%) }\end{array}$ & Kriteria \\
\hline 1 & 43 & 9 & 52 & 251 & 4,8 & 96,54 & Sangat efektif \\
2 & 46 & 6 & 52 & 254 & 4,9 & 97,69 & Sangat efektif \\
3 & 46 & 6 & 52 & 254 & 4,9 & 97,69 & Sangat efektif \\
4 & 35 & 1 & 52 & 243 & 4,7 & 93,46 & Sangat efektif \\
& & 7 & & & & & \\
5 & 41 & 1 & 52 & 249 & 4,8 & 95,77 & Sangat efektif \\
& & 1 & & & & & \\
6 & 42 & 10 & 52 & 250 & 4,8 & 96,15 & Sangat efektif \\
7 & 41 & 1 & 52 & 249 & 4,8 & 95,77 & Sangat efektif \\
& & 21 & 52 & 239 & 4,6 & 91,92 & Sangat efektif \\
8 & 31 & 6 & 52 & 254 & 4,9 & 97,69 & Sangat efektif \\
9 & 46 & 9 & 52 & 251 & 4,8 & 96,54 & Sangat efektif \\
11 & 43 & 3 & 52 & 257 & 4,9 & 98,85 & Sangat efektif \\
12 & 49 & 3 & 52 & 257 & 4,9 & 98,85 & Sangat efektif \\
13 & 49 & 6 & 52 & 254 & 4,9 & 97,69 & Sangat efektif \\
14 & 46 & 6 & 52 & 254 & 4,9 & 97,69 & Sangat efektif \\
15 & 46 & 21 & 52 & 239 & 4,6 & 91,92 & Sangat efektif \\
& 31 & & Rata-rata TCR & & & 96,28 & Sangat efektif \\
\hline
\end{tabular}

Data Primer Diolah, 2020

Dari Tabel 1 dapat dilihat tanggapan responden melalui angket yang diberikan. Secara keseluruhan melalui tabel diperoleh hasil perhitungan rata-rata tanggapan responden bahwa terhadap program klaster Bank Indonesia Sumatera Utara pada petani cabai di Kelompok Juli Tani ditinjau dari variabel input (kinerja program klaster) adalah sebesar 96,28 persen dan berada pada interval 90 persen-100 persen. Hal ini berarti tingkat efektivitas variabel input (kinerja program klaster) masuk dalam katagori sangat efektif.

Selanjutnya, berikut distribusi frekuensi jawaban 52 orang responden dari masing- masing indikator variabel output (produksi usaha tani) efektivitas Klaster Bank Indonesia pada petani cabai di Kelompok Juli Tani, dapat dilihat pada Tabel 2.

Tabel 2. Distribusi Frekuensi Jawaban Responden dari Indikator Variabel output Efektivitas Program Klaster Pada Petani Cabai di Kelompok Juli Tani

\begin{tabular}{cccccccc}
\hline Pernyataan & SS & S & Jumlah & $\begin{array}{c}\text { Total } \\
\text { skor }\end{array}$ & $\begin{array}{c}\text { Rata- } \\
\text { rata }\end{array}$ & $\begin{array}{c}\text { Tcr } \\
\text { (\%) }\end{array}$ & Kriteria \\
\hline 1 & 43 & 9 & 52 & 251 & 4,8 & 96,54 & Sangat efektif \\
2 & 42 & 10 & 52 & 250 & 4,8 & 96,15 & Sangat efektif \\
3 & 48 & 4 & 52 & 256 & 4,9 & 98,46 & Sangat efektif \\
4 & 41 & 11 & 52 & 249 & 4,8 & 95,77 & Sangat efektif \\
5 & 46 & 6 & 52 & 254 & 4,9 & 97,69 & Sangat efektif
\end{tabular}


Rinaldi Simamora, Ahmad Rafiqi Tantawi, \& Mitra Musika Lubis, Efektivitas Program Klaster Bank Indonesia Terhadap Peningkatan Pendapatan Petani Cabai Kelompok Juli Tani

$\begin{array}{llll}\text { Rata-rata TCR } & 4,8 & 96,92 & \text { Sangat efektif }\end{array}$

Data Primer Diolah, 2020

Dari Tabel 2 diperoleh hasil perhitungan rata-rata tanggapan responden bahwa terhadap program klaster Bank Indonesia Sumatera Utara pada petani cabai di Kelompok Juli Tani ditinjau dari variabel output (produksi usaha tani) adalah sebesar 96,92 persen dan berada pada interval 90 persen100 persen. Hal ini berarti tingkat efektivitas variabel output (produksi usahatani) masuk dalam katagori sangat efektif.

Berdasarkan hasil perhitungan efektivitas program klaster Bank Indonesia Sumatera Utara pada petani cabai di Kelompok Juli Tani ditinjau dari variabel input (kinerja program klaster) dan output, maka diperoleh rata-rata tanggapan responden sebesar 96,44 persen sehingga dikategorikan sangat efektif karena berada pada interval 90 persen - 100 persen.

\section{Analisis Pendapatan Usaha Tani}

Pendapatan usaha tani yang dimaksud dalam penelitian adalah pendapatan usaha tani cabai pada Kelompok Juli Tani (yang mengikuti program klaster Bank Indonesia Sumatera Utara) dan usaha tani Cabai pada Kelompok Sabar Tani yang terletak pada Desa Karang Anyar, Kecamatan Beringin (tidak mengikuti program klaster) yang diperoleh dalam satu kali musim panen. Rata- rata pendapatan pada usaha tani cabai di daerah penelitian (KelompokJuli Tani) dan sabar tani dapat dilihat pada Tabel3.

Tabel 3. Rata-rata Pendapatan Usaha Tani Cabai pada Kelompok Juli Tani dan Kelompok Sabar Tani

\begin{tabular}{llcccc}
\hline No & Kelompok Tani & $\begin{array}{c}\text { Produksi } \\
(\mathbf{K g})\end{array}$ & $\begin{array}{c}\text { Total } \\
\text { Penerimaan } \\
(\mathbf{R p})\end{array}$ & $\begin{array}{c}\text { Biaya Produksi } \\
\text { (Rp) }\end{array}$ & $\begin{array}{c}\text { Total } \\
\text { Pendapatan } \\
\text { (Rp) }\end{array}$ \\
\hline $\mathbf{1}$ & Kelompok Juli Tani & 4.688 & 140.653 .846 & 23.248 .951 & 117.404 .895 \\
2 & Kelompok Sabar Tani & 3.936 & 64.476 .000 & 19.607 .200 & 44.868 .800 \\
\hline
\end{tabular}

Data Primer Diolah, 2020

Dari tabel di atas dijelaskan bahwa total penerimaan usaha tani cabai pada Kelompok Juli Tani (yang mengikuti program klaster) per musim tanam sebesar Rp 140.653.846 dan biaya produksi yang dikeluarkan selama semusim sebesar Rp 23.248.954 sehingga petani memperoleh pendapatan sebesar Rp 117.404.895 selama satu musim tanam. Sedangkantotal penerimaan usahatani cabai pada Kelompok SabarTani (yangtidakmengikuti program klaster) per musim tanam sebesar Rp 64.476.000 dan biaya produksi yang dikeluarkan selama semusim sebesar Rp 19.607.200 sehingga petani memperoleh pendapatan sebesar Rp 44.868.800.

Untuk melihat usaha tani ini menguntungkan atau tidakpeneliti menggunakan analisis (Revenue Cost Ratio R/C).yaitu :

$$
\mathrm{R} / \mathrm{C}=\mathrm{PT} / \mathrm{BT}
$$

Revenue Cost Ratio R/C Kelompok Juli Tani :

$$
\begin{gathered}
\mathrm{R} / \mathrm{C}=\frac{117.404 .895}{23.248 .951} \\
\mathrm{R} / \mathrm{C}=5,0
\end{gathered}
$$

Revenue Cost Ratio R/C Kelompok Sabar Tani:

$$
\begin{gathered}
\mathrm{R} / \mathrm{C}=\frac{44,868,800}{19,607,200} \\
\mathrm{R} / \mathrm{C}=2,3
\end{gathered}
$$

Sehingga usaha tani cabai dari kedua kelompok ini menguntungkan karena memiliki nila R/C Ratio > 1. 


\section{Komparasi Pendapatan Usaha Tani Cabai}

Dari data analisis pendapatan usaha tani cabai dapat dilihat perbedaanpendapatanantarakelompok Juli Tani dan KelompokSabar Tani sebesar Rp 72.536.095. Berdasarkan hasil observasi peneliti di lokasi penelitian, selain disebabkan oleh jumlah produksi hal ini juga disebabkan beberapa faktor seperti tata kelola budidaya usaha tani dan pasca panen.

Program Klaster Bank Indonesia Sumatera Utara pada Kelompok Juli Tani diberikan berupa pendampingan terhadap Kelompok Juli Tani. Adapun pendampingan yang diberikan oleh pihak Bank Indonesia berupa pendampingan terhadap managemen organisasi kelompok tani, tata kelola usaha tani yang lebih efisien hingga penanganan pasca panen. Sementara pada kelompok Sabar Tani sendiri menjalankan usaha taninya dengan cara konvensional dan tentunya kurang efisien dibandingkan dengan Kelompok Juli Tani sehingga hal ini mempengaruhi hasil produksi usaha tani itu sendiri.

Sedangkan untuk pemasaran hasil produknya para petani di Kelompok Juli Tani menjual hasil produksinya di Sub Terminal Agribisnis (STA) Kelompok Juli Tani yang dibentuk melalui program klaster Bank Indonesia. Dengan adanya STA ini hasil produksi dari para petani Kelompok Juli Tani sendiri lebih terjamin dengan harga yang stabil. Para petani cabai Kelompok Juli Tani menjual hasil produksi usaha tani cabainya ke STA dengan harga sebesar Rp 30.000/Kg. Harga ini jauh lebih tinggi dibandingkan dengan para petani cabai di Kelompok Sabar Tani yang menjual hasil usaha taninya ke tengkulak dengan kisaran harga antara Rp 15.000/Kg-Rp 18.000/Kg. Faktor ini jelas sangat mempengaruhi perbedaan pendapatan di kedua kelompok tani tersebut.

\section{Hasil Uji Rank Spearman}

Untuk melihat hubungan variabel input (kinerja program klaster) dan variable output (produksi usaha tani) peneliti menggunakan statistik non parametrik dengan uji korelasi Rank Spearman.

Tabel4.Hasil Uji Rank Spearman

\begin{tabular}{|c|c|c|c|c|}
\hline \multicolumn{5}{|c|}{ Correlations } \\
\hline \multirow{7}{*}{ Spearman's rho } & \multirow{4}{*}{$\begin{array}{l}\text { Variable } \\
\text { Kinerja } \\
\text { Program } \\
\text { Klaster }\end{array}$} & \multirow{3}{*}{$\begin{array}{l}\text { Correlation Coefficient } \\
\text { Sig. (2-tailed) }\end{array}$} & \multirow{2}{*}{$\begin{array}{l}\text { KINERJA } \\
\text { PROGRAM } \\
\text { KLASTER } \\
1.000\end{array}$} & \multirow{2}{*}{$\begin{array}{l}\text { PRODUKSI } \\
\text { USAHATANI } \\
\qquad .850^{* *}\end{array}$} \\
\hline & & & & \\
\hline & & & . & .000 \\
\hline & & $\mathrm{N}$ & 52 & 52 \\
\hline & $\begin{array}{l}\text { Variable } \\
\text { Produksi }\end{array}$ & Correlation Coefficient & $.850^{* *}$ & 1.000 \\
\hline & Usahatani & Sig. (2-tailed) & .000 & \\
\hline & & $\mathrm{N}$ & 52 & 52 \\
\hline
\end{tabular}


Rinaldi Simamora, Ahmad Rafiqi Tantawi, \& Mitra Musika Lubis, Efektivitas Program Klaster Bank Indonesia Terhadap Peningkatan Pendapatan Petani Cabai Kelompok Juli Tani

**. Correlation is significant at the 0.01 level (2-tailed).

Data Primer Diolah, 2020

Dari data di atas dapat dilihat bahwa nilai signifikansi sebesar 0,000, karena tingkat signifikansi $\leq 0,05$, maka hipotesis diterima dengan arah positif. Sehingga korelasi antara variable Kinerja Program Klaster dengan variabel produksi usaha tani dinyatakan positif dan signifikan.

\section{SIMPULAN}

Berdasarkan pada penjelasan-penjelasan sebelumnya maka penelitian ini dapat disimpulkan bahwa Program klaster Bank Indonesia sangat efektif terhadap tingkat pendapatan petani cabai pada Kelompok Juli Tani di Desa Sidodadi, Kecamatan Beringin, Kabupaten Deli Serdang. Peningkatan pendapatan petani cabai pada Kelompok Juli tani sangat signifikan dengan adanya program klaster dari Bank Indonesia Sumatera Utara dibandingkan dengan Kelompok Sabar Tani yaitu dengan selisih pendapatan sebesar Rp 72.536.095.

\section{DAFTAR PUSTAKA}

Dirjen Hortikultura. (2004). Kebijakan Teknis Pengendalian OPT. Jakarta: Ditjen Hortikultura.

DKBU Bank Indonesia. (2008). Percepatan Pertumbuhan Sektor Rill Melalui Kegiatan Pengembangan Klaster UMKM.

Kementerian Pertanian Republik Indonesia. (2019). Retrieved 2 September 2020, https://www.pertanian.go.id/home/index.php?show=repo\&fileNum=469

Rahardi, F. (2007). Agribisnis Buah-buahan. Jakarta: Penebar Swadaya.

Salvatore, D. (1996). Ekonomi Internasional. Jakarta: Erlangga.

Samuelson. (2006). Ilmu Makro Ekonomi. Jakarta: PT Media Global Edukasi.

Santika. (1999). Bertanam Cabai. Jakarta: Penebar Swadaya.

Soekartawi. (1993). Prinsip Dasar Ekonomi Pertanian Teori dan Aplikasinya. Jakarta: PT Raja Grafindo Persada.

Sugiyono. (2014). Metode Penelitian Kuantitatif, Kualitatif dan R\&D. Bandung: Alfabeta.

Zikria, V., Takahashi, K., \& Maeda, K. (2019). International Competitiveness of Indonesia's Cocoa Sector: From the Viewpoint of Product Differentiation. Journal Faculty of Agriculture, Kyushu University, 64(2), 407-413. 